Article

\title{
The Historical Memory of American Presidents in the Mass Public
}

\author{
Jeffrey E. Cohen \\ Department of Political Science, Fordham University, Bronx, NY 10458, USA; cohen@fordham.edu; \\ Tel.: +1-718-817-3956
}

Received: 26 December 2017; Accepted: 25 February 2018; Published: 2 March 2018

\begin{abstract}
This paper investigates public evaluations of past presidents. Since voters generally lack much historical knowledge, such evaluations are not useful indicators of the performance and effectiveness of presidents across history, unlike the greatness evaluations of experts, like historians and presidency scholars. Still, presidents may be concerned about how future generations of voters will think about them. These anticipations may then affect presidential behavior in office. This study uses a Rasmussen poll in 2007 that asked voters their assessment of all the past presidents, from George Washington through to George W. Bush. Results find that voters look upon past presidents more favorably as a larger number of voters have opinions about the president, presidents of the founding generation are looked upon more favorably, and the ratings of experts affect voters' assessments of past presidents. The conclusion discusses the implications of the results and offers suggestions for future research.
\end{abstract}

Keywords: presidential rankings; mass public; presidential greatness

\section{Introduction}

Ranking presidents from great to failure has evolved from a parlor game, initiated by Arthur Schlesinger, Sr. in 1948, to a scholarly pursuit today (Schlesinger 1948, 1962). Since those earliest greatness polls, presidential rankings have been periodically updated to include the most recent president and have been refined, for instance, by using numerical scores rather than ranks, and rating presidents on specified dimensions, like congressional relations, public relations, and/or moral authority, instead of only using the "great" to "failure" global assessments (e.g., C-SPAN 2000, 2009; Faber and Faber 1997; Felzenberg 2008; Lindgren and Calabresi 2000; Maranell 1970; Murray and Blessing 1994; Ridings and McIver 1997; Rottinghaus and Vaughn 2015; Schlesinger 1997; Sienna College Research Institute 2010).

Moreover, there is now a voluminous literature analyzing the greatness assessments of experts (Balz 2010; Bose and Landis 2003; Curry and Morris 2010; Deluga 1998; Kenney and Rice 1988; Maranell 1970; Maranell and Dodder 1970; McCann 1992, 1995, 2005; Newman and Davis 2016; Nice 1984; Nichols 2012; Simon and Uscinski 2012; Simonton 1987, 1991, 1992, 1993, 2001, 2002, 2006, 2008; Uscinski and Simon 2011). One rationale for the analysis of rankings is their consistency over time-presidents that are rated highly in one survey tend to be rated highly in the others. The same can be said of those rated in the middle and bottom ranks. Aggregating across raters cancels out the idiosyncratic assessments of individual raters, thus justifying analysis of these greatness surveys. This consistency has led Dean Keith Simonton, perhaps the most prominent scholar of presidential greatness polls, to argue that there is "an almost objective consensus" of these subjective evaluations (Simonton 2013, p. 328). Moreover, analyses of the greatness polls have been successful, at least in a statistical sense-routinely studies report $\mathrm{R}^{2} \mathrm{~s}$ from the $80 \%$ range or higher.

In contrast to the large literature analyzing experts' greatness ratings, there is much less research on the ratings of nonexperts, such as voters. One reason for the paucity of such research is that there is 
relatively little data. But, another reason may be skepticism about the meaningfulness of nonexpert, voter ratings of presidents. The public is notorious for its lack of information and interest in politics and public affairs (Delli Carpini and Keeter 1997); the same can be said about its knowledge of American and presidential history.

Yet, if the public's rankings of presidents over the nation's history might not be in themselves meaningful indicators of the performance, effectiveness, leadership, and/or greatness of presidents, it does not mean that the historical reputation of presidents in the mass public are meaningless. For instance, great store has been put into the contemporaneous public assessment of presidents, the important literature on presidential approval.

The public's historical understanding of presidents is important for several reasons. First, as Panagopoulos argues, "speculation about how presidential actions will be viewed by future generations weighs heavily on the minds of chief executives", (Panagopoulos 2012, p. 719). In making decisions, presidents consider the potential impact on their reputation. Second, by analyzing the public's historical assessments, we learn something about how the public learns about American politics and history and whether or not the public employs the same or different criteria than the experts in assessing past presidents (Thies 2014). To these ends, this paper analyzes a little-known survey of the mass public by the Rasmussen poll in $2007 .^{1}$

The next section reviews the sparse research on mass public assessments of presidents historically, followed by a theory to explain those historical assessments. Then the paper presents and discusses the data from the 2007 Rasmussen poll, followed by the analysis. Results indicate that expert ratings have a strong influence on the public's assessments of presidents, that the public tends to view the earliest presidents most positively, and the public also views the more recognizable presidents more positively. The conclusion discusses the implications of the findings for understanding the presidency in the mass public and offers directions for future research.

\section{Research on the Nonexpert Ratings of Presidents}

There are only five papers that investigate the public's assessments of presidents from an historical perspective. King (1999) is the first to investigate voters' assessments of past presidencies. He uses Gallup polls from 1990 and 1993, which asked voters whether they approved or disapproved of past presidents from Harry Truman through Ronald Reagan. Despite the small n's, he finds that the economy during the past president's term and whether there was an unpopular war significantly affected these retrospective evaluations (p. 170). He also found a strong correlation between historians' greatness ratings and voters' retrospective approval (p. 172), albeit with two major differences: the public seem to more highly regard Kennedy than the experts but gave Lyndon Johnson weaker ratings when compared to the experts.

Panagopoulos (2012) builds on King's work in several ways. First, he updates to include Gallup polls through 2010, and pools them into a common data set, for an effective $n$ of 69 . The greater $n$ allows him to perform a more extensive multivariate analysis, and he finds that mean approval while in office, final approval while in office, approval of the current incumbent, and years out of office all positively affect retrospective approval, but that deceased presidents are less well regarded than living ex-presidents.

Two studies leverage the 1999 Cable-Satellite Public Affairs Network (C-SPAN) presidential greatness poll, in which C-SPAN viewers were allowed to respond to the same survey on all presidents as experts on the office (Cohen 2003; Endersby and Towle 2003). Among the important innovations of the C-SPAN poll was to ask about presidential performance in ten categories, instead of just asking raters for their global

1 This is to my knowledge, the only such poll of the mass public on all presidents for which data can be located publicly. Thies (2014, footnote 21) reports on similar polls by Zogby International, but the links are no longer active. The Rasmussen poll results available on Wikipedia, which I accessed on 11 February 2017, at: https:/ / en.wikipedia.org/wiki/Historical_ rankings_of_presidents_of_the_United_States. 
evaluation. Still, C-SPAN's viewers probably differ markedly from average voters: they are likely much more interested, knowledgeable, and informed about politics and history in general, and the presidency in particular. Despite the differences in theoretical models, Cohen and Endersby-Towle find great similarity between the nonexpert and expert evaluations of the presidents. Cohen, for instance, finds that the core six Simonton variables (years in office, wartime presidency, scandal, assassination, being a war hero and intellectual brilliance) affect both the experts and nonexperts' historical views of presidents. Endersby and Towle find that the experts' ratings have a positive and strong impact on nonexpert ratings. ${ }^{2}$

Finally, in a recent paper, Thies (2014) imaginatively compared the greatness rankings by experts with those of the mass public. Thies's analysis of the evaluations of the mass public, rather than just the informed public, such as C-SPAN viewers, is important and instructive. His basic finding is that ordinary people judge past presidents often quite differently from the experts. Where the mass public rewards a president for presiding over a good war and punishes for a scandal, for the experts, both good and bad wars improve presidential reputations, as does economic performance, while scandal hurts.

But there are several limitations of his analysis. First, he employs a paired down empirical model, which consists of two economic variables, a war variable and a scandal variable, but does not include numerous other variables found to be important predictors of presidential greatness, such as intellectual brilliance, war hero status, and years in office. Second, his analysis of expert ratings includes all past presidents, but for his mass public analysis he splits distant past presidents (20 years prior to the survey date) from more recent ones, although in his expert analysis he includes variables for how long the president has been out of office at the time of the expert survey. Third, the experts and mass public are administered very different questions. While the experts are asked to assess presidents on a greatness scale, the mass public in the Rasmussen poll was asked if they had a favorable, unfavorable, or don't know impression of each past president, leading to the question of whether these scaling/question wording differences may account for the discrepancies in the evaluation standards of experts and the mass public. Finally, Thies did not make use of the fact that large numbers of voters had no opinion about a large number of presidents.

Thies's study raises a number of questions. First, are the presidential assessment of the mass public meaningful? Does it make much sense to analyze the public's historical rankings of presidents when most know so little about all, but a small number of mostly recent presidents. Second, Endersby and Towle present a theory that argues that experts are opinion leaders, and that the mass public, by and large, adopts the evaluations of experts, not so much by paying attention directly to the experts, but by the way that expert evaluations of presidents pervades political discourse and popular culture. Endersby and Towle, however, only test their model on the informed public, who we would expect to be more attuned to the expert ratings, either directly or indirectly, than average voters, who pay much less attention to these matters. Thies finds large differences in the evaluation criteria of experts and the mass public counters the Endersby-Towle theory. Thus, there are some notable differences and controversies in this literature, despite its small size. The next section offers a theoretical model to account for voters' historical evaluations of presidents.

\section{A Theory of Voters Historical Assessments of Ex-Presidents}

Implicit in much of the research on presidential greatness is that these rankings and scores are meaningful reflections on actual presidential performance and effectiveness. For instance, Simonton (Simonton 2001, p. 294) states that, "there is a strong prima facie case that these greatness assessments reveal how U.S. presidents varied in their effectiveness as the nation's highest political leader". But, voters' historical evaluations should not be treated similarly, and are better viewed only as

2 They also analyze a broader set of C-SPAN viewers who only rated, in a short instrument, their top 10 and bottom five presidents, but as they point out, there are issues with the resulting data, which only classifies presidents into three categories, those receiving the most top ten votes, a bottom category of those with the most bottom 5 votes, and a middle category of the rest. 
opinions, with voters being sometimes informed about ex-presidents, but, perhaps more commonly, not much informed about them. Thus, we ask the questions, what factors account for voters' historical assessments of presidents? What are the properties of such voter opinions?

Second, although non-attitudes might characterize a lot of the "opinions" of voters about a lot of presidents, the data used here are aggregate, not individual, level. In fact, we do not possess individual level voters' opinions. But these aggregate opinions are probably more meaningful than individual level opinion on past presidents. One of the properties of aggregation of opinion is that noise (e.g., non-attitudes) is canceled out, providing us with a clearer signal about the public's opinion (Page and Shapiro 1992; Erikson et al. 2002).

Third, given that voters, on average, are relatively disinterested and uninformed about American politics, history (Naseem 2015), and much of what presidents' currently do and previously did, how do voters form opinions about the presidents in historical comparison? Voters learn of the presidency primarily from two sources-schools when they are young (Niemi and Junn 2005) and the news media as adults. (Bartels 1993; Jerit et al. 2006; Prior 2005). Both of the sources present voters with essentially the same portrait and types of information about presidents, which emphasizes the handful of presidents conventionally recognized as "great".

American schools teach about the presidency from the "heroic" perspective, the textbook presidency approach. ${ }^{3}$ That perspective emphasizes presidents as individuals, rather than as leaders embedded in a constitutional and institutional setting. Presidential achievement results from the efforts of individual presidents, rather than the workings of the political system. Thus, a handful of presidents receive inordinate coverage and attention, while most may not even be mentioned (Connolly 2007). But presidents at the bottom of the list, the failures, may also not receive much attention. Doing so would undermine the heroic interpretation of the office and its occupants, exposing potential weaknesses of the system, for instance, that voters sometimes select "bad" presidents and/or that the political system does not always work as advertised or promised. To a degree, experts' renderings of presidential greatness determines how and which presidents are discussed in civics and history textbooks.

Furthermore, textbooks idealize the founders, collectively portraying them as upstanding geniuses that were prescient about the ability of the constitutional system that they designed to deal with the future political problems of the nation. Thus, school children are likely to know the names of many of the founders who became president, as well as something about them, for instance, the honesty and heroism of George Washington, that James Madison wrote much of the Constitution, that Thomas Jefferson wrote the Declaration of Independence and purchased the Louisiana territory, that James Monroe gave us a foreign policy approach (the Monroe doctrine) that lasted for over a century, and that during Andrew Jackson's time the franchise expanded, but Native Americans suffered. As a result of civics and presidency education in American high schools, students will possess limited knowledge and understanding of the political system, how it operates, and its political history (Feinberg and Doppen 2010).

The news media, the second major source of information for voters about presidents, generally reiterates the textbook presidency model. Again, news reporting personalizes the presidency, emphasizing the traits of individuals in office and the heroic conceptions of the president's role in the political system. Voters, consequently, develop heightened expectations of the potential of presidential leadership, with little knowledge or regard for the constitutional and political constraints on presidents (Simon 2009; Waterman et al. 2014). As institutions focused on presenting information on current events to viewers and readers, the news media presents little information or content on historical presidencies. When it does, it is draws parallels and comparisons between the behaviors and activities of current incumbents with earlier presidents. For instance, when Barack Obama appeared to back away from his post-partisanship approach in dealing with Congress for a more partisan strategy, commentators remarked on Harry

3 The term "the textbook presidency" was first coined by Cronin (1974). Also see (Adler 2005; Alsfeld 1995; Hoekstra 1982; Roberts and Butler 2012; Sanchez 1996a, 1996b; Zernicke 1993). 
Truman's re-election bid in 1948 as a template for Obama's shift in strategy. ${ }^{4}$ One occasion when the news media discusses ex-presidents is when the latest presidential greatness poll is released. These stories tend to be topline focused, mentioning those who head the list, but usually little more, unless it is buried deep into the story. Rarely, do these news reports present the complete list from these greatness tallies. ${ }^{5}$

Furthermore, voters are likely to be more critical of recent ex-presidents than those who severed some time ago. Orientations of recently termed presidents will be colored strongly by voters' political predispositions; the image of recent ex-presidents will still be mired in the political and policy controversies that animate current politics. As time goes on, the positions of ex-presidents on issues begins to fade from public memory and their presidencies are re-evaluated, which is usually to the upside. Moreover, as the details of the ex-president's tenure begin to fade, the more temporally distant ex-presidents begin to look better than sitting or recent incumbents, for whom voters may more easily recall what they disliked about them.

Thus, from these two sources of information on ex-presidents, students and voters may learn the names of the great presidents, something about important accomplishments and/or dramatic events during their tenures (including major scandals), as well as something about the personal attributes of presidents. The above discussion leads to several hypotheses about public evaluations of ex-presidents historically:

H1. In evaluating ex-presidents, the percentage of "Don't Knows" will be inversely related to the president's ranking".

H2. In evaluating ex-presidents, earlier presidents will receive higher rating from voters than more recent presidents.

H3. In evaluating ex-presidents, the ratings of experts will be positively associated with voters' assessments.

\section{Data}

The data on mass public evaluations of historical presidents comes from a 2007 Rasmussen poll. As noted above, that poll asked voters whether they had a favorable or unfavorable impression of each of the presidents who served since George Washington, allowing respondents a "Don't Know" option (see above, and (Thies 2014)). Table 1 presents these data.

Table 1. Mass Public Favorability to Past Presidents.

\begin{tabular}{cccccc}
\hline Name & Favorable & Unfavorable & Favorability Rate & Don't Know & C-SPAN Expert Rating 2009 \\
\hline Washington & 94 & 2 & 98 & 4 & 854 \\
J. Adams & 74 & 9 & 89 & 17 & 545 \\
Jefferson & 89 & 4 & 96 & 7 & 698 \\
Madison & 73 & 8 & 90 & 19 & 535 \\
Monroe & 49 & 10 & 83 & 41 & 605 \\
J. Q. Adams & 59 & 7 & 89 & 34 & 542 \\
Jackson & 69 & 14 & 83 & 17 & 606 \\
Van Buren & 23 & 19 & 55 & 58 & 435 \\
Tyler & 9 & 15 & 38 & 76 & 372 \\
W.H. Harrison & 21 & 16 & 57 & 63 & 324 \\
\hline
\end{tabular}

4 “Obama as Truman: “Give em hell, Barry?” CNN.com, accessed 15 March 2017, at www.cnn.com/2011/POLITICS/09/09/ obama.truman/.

5 “New Ranking of U.S. Presidents puts Lincoln at No. 1, Obama at 18." Washington Post, accessed on 15 March 2017, at https:/ / www.washingtonpost.com/news/monkey-cage/wp/2015/02/16/new-ranking-of-u-s-presidents-puts-lincoln1-obama-18-kennedy-judged-most-over-rated/?utm_term=.5d0ba4ca0f4a. 
Table 1. Cont.

\begin{tabular}{cccccc}
\hline Name & Favorable & Unfavorable & Favorability Rate & Don't Know & C-SPAN Expert Rating 2009 \\
\hline Taylor & 26 & 18 & 59 & 56 & 443 \\
Polk & 27 & 21 & 56 & 52 & 606 \\
Fillmore & 17 & 25 & 42 & 58 & 351 \\
Pierce & 17 & 25 & 42 & 58 & 287 \\
Buchanan & 28 & 32 & 47 & 40 & 902 \\
Lincoln & 92 & 4 & 96 & 4 & 258 \\
A. Johnson & 45 & 26 & 63 & 29 & 490 \\
Grant & 58 & 24 & 70 & 18 & 409 \\
Hayes & 38 & 19 & 67 & 43 & 445 \\
Garfield & 42 & 16 & 72 & 42 & 420 \\
Arthur & 43 & 17 & 72 & 40 & 523 \\
Cleveland & 40 & 26 & 61 & 34 & 442 \\
B. Harrison & 30 & 35 & 46 & 35 & 599 \\
McKinley & 42 & 24 & 75 & 34 & 485 \\
T. Roosevelt & 84 & 8 & 91 & 8 & 683 \\
Taft & 57 & 15 & 79 & 28 & 327 \\
Wilson & 56 & 19 & 75 & 25 & 469 \\
Harding & 29 & 33 & 47 & 38 & 389 \\
Coolidge & 38 & 31 & 55 & 31 & 837 \\
Hoover & 48 & 34 & 59 & 18 & 708 \\
F. Roosevelt & 81 & 12 & 87 & 7 & 689 \\
Truman & 70 & 14 & 83 & 16 & 701 \\
Eisenhower & 72 & 15 & 83 & 13 & 641 \\
Kennedy & 80 & 13 & 86 & 7 & 450 \\
L. Johnson & 45 & 42 & 52 & 13 & 509 \\
Nixon & 32 & 60 & 35 & 8 & 474 \\
Ford & 62 & 26 & 70 & 12 & 671 \\
Carter & 57 & 34 & 63 & 9 & 605 \\
Reagan & 72 & 22 & 77 & 6 & \\
G. H. W. Bush & 57 & 41 & 58 & 2 & \\
Clinton & 55 & 41 & 57 & 4 & \\
G. W. Bush & 41 & 59 & 41 & 0 & \\
\hline & & $50 u r c e: ~$ & 2007 Rasmussen Poll, and C-SPAN. See text for details. & \\
& & & & \\
\end{tabular}

On Table 1, Favorability Rate, the dependent variable that was used in this analysis, is defined as the percentage favorable divided by the percentage favorable and unfavorable $\{($ favorable $\%) /($ favorable $\%+$ unfavorable $\%)\}$. A score of 50 indicates that the same percentage of voters think positively and negatively about a president. Several presidents have scores below 50 , indicating more who think negatively than positively about a president. Richard Nixon has the lowest score at 35 , followed by Tyler at 38, G. W. Bush at 41, Filmore and Pierce at 42, Buchanan and Harding at 47, for the presidents with scores below 50 . All of these presidents tend to rank at the bottom by experts. Yet, the percentage of voters' "Don't Know" responses varies considerably, with small "Don't Know" responses for Nixon and Bush, but large "Don't Know" percentages for the others. Furthermore, several presidents usually ranked poorly by experts possess relatively positively voters' evaluations, in particular Grant and Hoover.

Several presidents have very high favorability ratings of $90 \%$ or greater. Washington tops the list at 98, with Jefferson and Lincoln at 96, Theodore Roosevelt at 91, and Madison at 90. All also tend to be ranked quite highly by experts. Notably, however, Franklin Roosevelt, usually ranked third by the experts, just below Washington and Lincoln, has a voter score of 87 , while strong, is quite low when compared to other presidents that experts highly rank. Thus, from this initial look, there are some discrepancies between the way that voters and experts rank presidents.

The percentage "Don't Know", necessary to test Hypothesis 1, varies from very low, most common for recent and historically notable presidents (e.g., Washington, Lincoln) to as high as $76 \%$ (Tyler). Generally, the rate of "Don't Know" responses increases after the founding generation has left office (e.g., Van Buren) through Coolidge, although the "Don't Know" rate is quite high for two founders, Monroe (41) and John Quincy Adams (34). Across all presidents, the average "Don't Know" rate is 
$26.8 \%$, with a standard deviation of $19.9 \%$. Finally, to measure experts' ratings of presidents, necessary to test Hypothesis 3, I use the 2009 C-SPAN global rating, which is also presented on Table 1.6

\section{Analysis}

Table 2, Model 1, presents the results of regressing the favorability rate on three variables: the 2009 C-SPAN expert scores, the "Don't Know" \%, and the year the president entered office. The statistical analysis uses linear multiple regression. The fit for the three-variable estimation is impressive with an $R^{2}$ of 0.73 , all three of the variables are statistically significant at the 0.05 level, and point in the correct direction.

Table 2. Impact of Expert Ratings, Percentage of "Don't Knows" and Year in Office on Mass Public Favorability towards Presidents.

\begin{tabular}{|c|c|c|c|}
\hline VARIABLES & Model 1 & Model 2 & Model 3 \\
\hline C-SPAN 2009 Score & $\begin{array}{c}0.06^{* * *} \\
(0.01)\end{array}$ & $\begin{array}{c}0.06^{* * *} \\
(0.01)\end{array}$ & $\begin{array}{c}0.06^{* * *} \\
(0.01)\end{array}$ \\
\hline "Don't Know" \% & $\begin{array}{c}-0.38^{* * *} \\
(0.12)\end{array}$ & $\begin{array}{c}-0.37^{* * *} \\
(0.011)\end{array}$ & $\begin{array}{l}-0.14 \\
(0.15)\end{array}$ \\
\hline First Year in Office & $\begin{array}{c}-0.15^{* * *} \\
(0.03)\end{array}$ & $\begin{array}{c}-0.12 \text { *** } \\
(0.03)\end{array}$ & $\begin{array}{c}-0.30 * \\
(0.13)\end{array}$ \\
\hline Real GDP Growth & & $\begin{array}{l}-0.72 \\
(0.46)\end{array}$ & $\begin{array}{l}-0.85 \\
(0.46)\end{array}$ \\
\hline Unpopular War & & $\begin{array}{c}-13.19 * * \\
(4.34)\end{array}$ & $\begin{array}{c}-13.66^{* *} \\
-4.41\end{array}$ \\
\hline Party Era 2 & & & $\begin{array}{l}-7.82 \\
(6.81)\end{array}$ \\
\hline Party Era 3 & & & $\begin{array}{c}6.37 \\
(9.63)\end{array}$ \\
\hline Party Era 4 & & & $\begin{array}{c}15.74 \\
(14.96)\end{array}$ \\
\hline Party Era 5 & & & $\begin{array}{c}30.59 \\
(21.46)\end{array}$ \\
\hline Party Era 6 & & & $\begin{array}{c}29.50 \\
(25.86)\end{array}$ \\
\hline Constant & $\begin{array}{c}338.50 * * * \\
(63.69)\end{array}$ & $\begin{array}{c}280.17^{* * *} \\
(58.81)\end{array}$ & $\begin{array}{l}600.56 * \\
(243.76)\end{array}$ \\
\hline $\mathrm{N}$ & 42 & 40 & 40 \\
\hline$R^{2}$ & 0.73 & 0.81 & 0.85 \\
\hline Adj. $R^{2}$ & 0.70 & 0.78 & 0.80 \\
\hline $\mathrm{F}$ & 33.41 & 28.75 & 16.82 \\
\hline RMSE & 9.803 & 8.60 & 8.16 \\
\hline RSS & 3652 & 2514 & 1933 \\
\hline
\end{tabular}

Turning to the individual coefficients, the historical ratings of the experts strongly influence mass public favorability of the presidents. As experts more highly regard the presidents, so does the mass

6 The C-SPAN 2009 poll asked experts their historical president evaluations. The original C-SPAN data can be found at C-SPAN. 2009. "Survey of Presidential Leadership." http:/ / legacy.c-span.org/PresidentialSurvey/Overall-Ranking.aspx, which is no longer available. I retrieved the C-SPAN data using the Wayback Machine on 2 February 2017. 
public. The expert ratings range from 0-1000, with a mean of 529 and a standard deviation of 163. A one standard deviation increase in the experts' rating produces a $9.7 \%$ rise in the favorability rate. Consider the implications for an average-rated president by the mass public (67.4). Based on this simulation, the average president's rate score becomes 77.1, which would move the president's ranking from about 21st (Hayes) to about 14th (Reagan). Thus, while a standard deviation effect of experts does not move the rankings of presidents from the middle of the pack to the top, this simulation demonstrates the strong pull of expert ratings on public assessments of the presidents.

The percentage "Don't Knows" also has a pronounced effect on the public assessments of past presidents, with regression coefficients of -0.38 . On average across all presidents, about $26.7 \%$ of respondents' answer "Don't Know" with a standard deviation of 19.9. Recall, there is a positivity bias in public perceptions of presidents historically_voters know more about the highly regarded than the middle or bottom ranked presidents. With this in mind, and assuming that decreases in "Don't Know" percentages does not also indicate greater information or discrimination by voters about the presidents, a one-standard deviation decrease in the percentage of "Don't Know" responses would lead to about a 7.5 favorability rate increase. This translates into the average president having a 74.9 rate score, in other words, moving the average president from the 21 st to the 16 th rank for the rate score, which is about the same as Woodrow Wilson.

Third, voters have more positive regard for earlier than more recent past presidents. According to the regression coefficients, each additional year earlier that a president served in office leads to a 0.15 improvement in a president's rate score. For example, if George Washington had assumed office in 1989 instead of 1789, his favorability rate score would fall from 98 to 68, leading him to rank about 24th, alongside Jimmy Carter. Although a dramatic example, it illustrates the effect of being one of the presidents of the founding generation compared to being in office more recently.

Model 2 on Table 2 adds the two variables that King (1999) found important in his study of voters retrospective evaluations of presidents, economic performance, and whether there was an unpopular war during the president's term in office. King justifies using these variables because they have been important in analyses of presidential approval ratings (p. 168). The Gallup data that he uses, for presidents from Truman through George H. W. Bush, also uses the job approval rating question for the retrospective evaluations of these presidents. The primary issue in using economic performance and unpopular war for the longer series of presidents used here is that voters may not know about either economic performance or the popularity of wars long into the past.

To measure economic performance, I use Curry and Morris (2010) measure, which compares real Gross Domestic Product (GDP) per capita at the beginning with the end of the president's term in office. $^{7}$ This differs from King (1999), who used the Misery Index, the addition of the unemployment and inflation rates, but unemployment rate data are not available prior to the late 1920s. Following King, I classify the Korean and Vietnam wars as unpopular, with three presidents in office and associated with those wars, Truman, Lyndon Johnson, and Nixon. To these wars, I add the Second Iraq and the Mexican-American wars, adding two more presidents to the list of those in office during unpopular wars, George W. Bush and James K. Polk. The unpopular war variable, like in King (1999) is measured as a dummy variable, $1=$ unpopular war president, $0=$ otherwise.

Results of this analysis find, similarly to King, that unpopular wars lower a president's favorability rating, by slightly over 13 percentage points. In contrast, GDP growth not only fails to reach statistical significance, it also points in the wrong direction, with a negative sign, although the hypothesis predicts a positive sign. Finally, the addition of the economic and war variables does not affect the statistical performance of the three variables discussed above, the experts' rating, the percentage of "Don't Know" responses, and when the president served in office.

7 There is no economic data for William Henry Harrison and James A. Garfield due to their very short terms in office. Thus, the $\mathrm{n}$ for analysis drops from 42 to 40 . 
Finally, there is the possibility that the effect of time in office on these retrospective evaluations may be non-linear, rather than linear as the measured using the first year in office variable. For instance, the gap in knowledge about presidents may be small in the years after the founders' generation, but may widen when we get to presidents in the mid-twentieth century. In other words, there may be a similar gap in voter knowledge about presidents Fillmore, Pierce, and Buchanan. But, there may a difference in the gap of voter knowledge about Coolidge and Hoover when compared to Eisenhower and Kennedy. To test this idea, I created six dummy variables that correspond to different party systems: (1) Washington-J. Q. Adams; (2) Jackson-Buchanan; (3) Lincoln-McKinley; (4) T. Roosevelt-Hoover; (5) FDR-Carter; and, (6) Reagan-Bush. This categorization of party eras comes from LeMay (LeMay 2017). Then I added the dummies for the party eras two through six into the equation from Table 2, Model 2. Results are presented on Table 2, Model 3.

It is difficult to interpret the individual regression coefficients for first year in office, the "Don't Know" percentage, and the party system dummies, since they are highly correlated, leading to multicollinearity. There is a suggestion that the inclusion of the party era dummies might increase model fit as the $\mathrm{R}^{2}$ rises from 0.82 (Model 2) to 0.85 (Model 3). However, neither the Akaike AIC nor the Schwarz's Bayesian (BIC) information criteria suggest that the addition of the party system dummies improves estimation performance, as the AIC and BIC statistics are smaller for the estimation from Model 2 than Model $3 .^{8}$

\section{Analysis of Residuals}

Finally, we can assess the overall performance of our model by inspecting the residuals for the two estimations to see if there are any patterns that would lead to inclusion of other factors hypothesized to affect public assessments of the presidents. Table 3 lists the residuals from largest positive to largest negative for the two estimations. The positive residuals indicate that the model under-predicts the presidents' favorability scores, that is, predicts lower scores than received from voters, with the negative residuals indicating over-predicting, that is, higher scores than received from the public.

Table 3. Residuals Based on Estimation from Model 2, Table 2.

\begin{tabular}{cc}
\hline Harry S. Truman & 17.8 \\
William Howard Taft & 15.8 \\
John Quincy Adams & 13.0 \\
Rutherford B. Hayes & 12.9 \\
Chester Arthur & 11.0 \\
Gerald Ford & 9.3 \\
John F. Kennedy & 9.1 \\
James Madison & 7.4 \\
Andrew Johnson & 7.2 \\
Dwight D. Eisenhower & 5.9 \\
James Monroe & 5.1 \\
John Adams & 4.8 \\
Warren G. Harding & 3.4 \\
Ronald Reagan & 3.0 \\
Franklin Delano Roosevelt & 1.8 \\
Jimmy Carter & 1.8 \\
Zachary Taylor & 0.7 \\
George W. Bush & 0.2 \\
James K. Polk & 0.2 \\
Theodore Roosevelt & -1.2 \\
Ulysses S. Grant & -1.3 \\
\hline
\end{tabular}

8 The AIC and BIC statistics for Model 2 are 294.7371 and 304.8704, respectively, while the AIC and BIC statistics for Model 3 are 295.9858 and 314.5635. 
Table 3. Cont.

\begin{tabular}{cc}
\hline Andrew Jackson & -1.3 \\
James Buchanan & -1.8 \\
Woodrow Wilson & -2.5 \\
Thomas Jefferson & -3.8 \\
William McKinley & -4.0 \\
Calvin Coolidge & -4.4 \\
Martin Van Buren & -4.5 \\
Lyndon Baines Johnson & -5.5 \\
Millard Fillmore & -6.0 \\
Franklin Pierce & -6.4 \\
Abraham Lincoln & -6.8 \\
Grover Cleveland & -7.6 \\
Herbert Hoover & -8.0 \\
John Tyler & -8.5 \\
George H. W. Bush & -9.1 \\
George Washington & -11.0 \\
Bill Clinton & -11.2 \\
Richard Nixon & -12.7 \\
Benjamin Harrison & -13.0 \\
\hline
\end{tabular}

Using a cut-off of 10, Truman, Taft, J. Q. Adams, Hayes, and Arthur have large positive residuals, while Washington, Clinton, Nixon, and B. Harrison have large negatives ones. Both of these sets of presidents are heterogeneous. While all but Truman among this first set with large positives also have a large percentage of "Don't Know" responses, the same can be said of other presidents, as well as Benjamin Harrison in the large negative residual set. Also, two of the presidents with large negative residuals, Nixon and Clinton were plagued with major scandals during their tenures, there were major scandals for the Harding and Grant administrations, which tarnished the reputation of those presidents. Based on the visual inspection, there does not appear to be any discernible pattern in these residuals. ${ }^{9}$

\section{Conclusions}

This paper has investigated voter evaluations of ex-presidents. Although these voter evaluations should not be taken as reliable and valid indicators of presidential performance and effectiveness in office, because of the general lack of voter knowledge about the presidency and U. S. history, these evaluations are important to study for other reasons. First, presidents who are concerned with their historical legacy may modulate their behavior in office with an eye on how future generations of voters will evaluate them. Second, if these voters' evaluations are viewed as an opinion, it becomes useful to understand the factors that affect how voters evaluate presidents across history.

Analysis of a 2007 Rasmussen poll, which asked a nationally representative sample of voters whether they had a favorable or unfavorable opinion of all ex-presidents, from George Washington through George W. Bush, found several factors that were systematically associated with those evaluations. First, for many presidents, a large percentage of voters did not have an opinion. When they had an opinion, however, it tended to be more favorable than unfavorable, in other words, knowledge of the president breeds a favorable impression. This linkage between opinionation and favorability reinforces the heroic, personal, and textbook image of the presidency that is so prevalent in school textbooks and much news reporting on the office.

9 I also added several variables from Simonton's core model, including whether there was a scandal during the president's term, whether the president was a war hero, the president's intellectual brilliance score, whether the president was assassinated, and two not from Simonton's model, whether the president was a Democrat or a Republican. None of these additional variables proved to be statistically significant, which makes sense, especially for the Simonton variables, which previous research has found to be strong predictors of experts' ratings of presidents. Finally, the Ramsey Omitted Variable test statistic is also statistically insignificant: $\mathrm{F}(3,31)=2.33, p=0.09$. 
Second, voters viewed the presidents of the founding generation more favorably than later presidents. This probably reflects both the way history is taught in schools, as well as the near "deification" of the founders, portraying them as a generation of geniuses who could do no wrong. Such an attitude may affect current politics, as voters respond to political communications that attempt to link certain policies to an understanding of the founders' intent. There should be more research on this question and whether such messages in political discourse actually persuade voter positions on issues.

Third, results indicate that the greatness rankings of experts statistically influence voters' assessments of past presidents. Do the experts' rankings of presidents' influence voters because they view the experts as authoritative or is the pathway from expert rankings to voter assessments more subtle and indirect, because textbooks and news reporting incorporates experts' evaluations, at least implicating, if not directly citing the experts? Or is it the case that both experts and voters are responding to another factor unmeasured in this analysis. More research needs to be done on whether experts have a causal impact on voter assessments of presidential greatness.

Finally, presidents who served when there was an unpopular war had lower retrospective voter ratings than presidents in office without an unpopular war. As King (1999) points out, the conduct of foreign policy, especially U. S. war involvement has major implications for public approval of sitting presidents, as well as for voters' historical evaluations of presidents in the post-World War Two era. Findings here reinforce the importance of public support for war on evaluations of presidents across the entire sweep of U. S. history. This study opens up news questions regarding the linkage between war, and perhaps foreign policy more broadly, on voters' assessments and expectations of presidents, as well as the historical memory and appraisal of presidents.

This study, while uncovering some important properties of public evaluations of ex-presidents, still leaves some questions unanswered. When considering the dearth of data, if would be useful to have more polls like Rasmussen's 2007 survey, perhaps with different types of evaluation questions. Individual level data from such surveys would also useful for understanding how voter characteristics affect their evaluation of presidents. Beyond their education and knowledge or presidents, does political orientation affect how voters see past presidents? Thus, there are still outstanding questions about voters' the historical understanding of presidents, calling for more research to address these questions.

Conflicts of Interest: The author declares no conflicts of interest.

\section{References}

Adler, David G. 2005. The Law: Textbooks and the President's Constitutional Powers. Presidential Studies Quarterly 35: 376-88. [CrossRef]

Alsfeld, Richard W. 1995. The Presidency Reconfigured? The Textbook Presidency Yet Again. Presidential Studies Quarterly 25: 677-82.

Balz, John. 2010. Ready to Lead on Day One: Predicting Presidential Greatness from Political Experience. PS: Political Science and Politics 43: 487-92. [CrossRef]

Bartels, Larry M. 1993. Messages Received: The Political Impact of Media Exposure. American Political Science Review 87: 267-85. [CrossRef]

Bose, Meene, and Mark Landis, eds. 2003. The Uses and Abuses of Presidential Ratings. New York: Nova Science Publishers.

Cohen, Jeffrey E. 2003. The Polls: Presidential Greatness as Seen in the Mass Public_An Extension and Application of the Simonton Model. Presidential Studies Quarterly 33: 913-24. [CrossRef]

Connolly, Christopher. 2007. Seven Presidents Nobody Remembers. CNN. October 1. Available online: http:// www.cnn.com/2007/LIVING/wayoflife/09/28/forgotten.presidents/index.html?eref=yahoo (accessed on 12 February 2017).

Cronin, Thomas E. 1974. The Textbook Presidency and Political Science. In Perspectives on the Presidency. Edited by Stephen, Bach and George T. Sulzner. Lexington: D.C. Heath, pp. 54-74.

C-SPAN. 2000. Survey of Presidential Leadership. Available online: http:/ / www.americanpresidents.org/survey (accessed on 2 February 2017). 
C-SPAN. 2009. Survey of Presidential Leadership. Available online: http:/ /legacy.c-span.org/PresidentialSurvey/ Overall-Ranking.aspx (accessed on 2 February 2017).

Curry, Jill L., and Irwin L. Morris. 2010. The Contemporary Presidency: Explaining Presidential Greatness: The Roles of Peace and Prosperity? Presidential Studies Quarterly 40: 515-30. [CrossRef]

Delli Carpini, Michael X., and Scott Keeter. 1997. What Americans Know About Politics and Why It Matters. New Haven: Yale University Press.

Deluga, Ronald J. 1998. American Presidential Proactivity, Charismatic Leadership, and Rated Performance. The Leadership Quarterly 9: 265-91. [CrossRef]

Endersby, James W., and Michael J. Towle. 2003. Perceptions of Presidential Greatness and the Flow of Evaluative Political Information: From the Elite to the Informed to the Masses. Politics \& Policy 31: 383-404.

Erikson, Robert S., Michael B. MacKuen, and James A. Stimson. 2002. The Macro Polity. New York: Cambridge University Press.

Faber, Charles, and Richard Faber. 1997. The American Presidents Ranked by Performance. Jefferson: McFarland.

Feinberg, Joseph R., and Frans H. Doppen. 2010. High School Students' Knowledge and Notions of Citizenship. The Social Studies 101: 111-16. [CrossRef]

Felzenberg, Alvin S. 2008. The Leaders We Deserved (and a Few We Didn't): Rethinking the Presidential Rating Game. New York: Basic Books.

Hoekstra, Douglas J. 1982. The ‘Textbook Presidency’ Revisited. Presidential Studies Quarterly 12: 159-67.

Jerit, Jennifer, Jason Barabas, and Toby Bolsen. 2006. Citizens, Knowledge, and the Information Environment. American Journal of Political Science 50: 266-82. [CrossRef]

Kenney, Patrick J., and Tom W. Rice. 1988. The Contextual Determination of Presidential Greatness. Presidential Studies Quarterly 18: 161-69.

King, James D. 1999. Looking Back at Chief Executives: Retrospective Presidential Approval. Presidential Studies Quarterly 29: 166-74. [CrossRef]

LeMay, Michael C. 2017. Background and History. In The American Political Party System. Edited by LeMay, Michael C. Santa Barbara: ABC-Clio, pp. 3-58.

Lindgren, James, and Steven G. Calabresi. 2000. Ranking the Presidents. Wall Street Journal, November 16. Available online: https:/ / www.wsj.com/articles/SB974336784441980753 (accessed on 15 March 2017).

Maranell, Gary M. 1970. The Evaluation of Presidents: An Extension of the Schlesinger Polls. The Journal of American History 57: 104-13. [CrossRef]

Maranell, Gary M., and Richard Dodder. 1970. Political Orientations and the Evaluation of Presidential Prestige: A Study of American Historians. Social Science Quarterly 51: 415-21.

McCann, Stewart J. H. 1992. Alternative Formulas to Predict the Greatness of U.S. Presidents: Personological, Situational, and Zeitgeist Factors. Journal of Personality and Social Psychology 62: 469-79. [CrossRef]

McCann, Stewart J. H. 1995. Presidential Candidate Age and Schlesinger's Cycles of American history (1789-1992): When Young Is Better. Political Psychology 16: 749-55. [CrossRef]

McCann, Stewart J. H. 2005. Simple Method for Predicting American Presidential Greatness from Victory Margin in Popular Vote (1825-1996). Journal of Social Psychology 145: 287-98. [CrossRef] [PubMed]

Murray, Robert K., and Tim H. Blessing. 1994. Greatness in the White House: Rating the Presidents from George Washington to Ronald Reagan, 2nd ed. University Park: Pennsylvania State University Press.

Naseem, Saba. 2015. How Much U.S. History Do Americans Actually Know? Less than You Think. Smithsonian Magazine. May 28. Available online: http:/ /www.smithsonianmag.com/history/how-much-us-history-doamericans-actually-know-less-you-think-180955431/ (accessed on 11 February 2017).

Newman, Brian, and Adrian Davis. 2016. Polls and Elections: Character and Political Time as Sources of Presidential Greatness. Presidential Studies Quarterly 46: 411-33. [CrossRef]

Nice, David C. 1984. The Influence of War and Party System Aging on the Ranking of Presidents. Western Political Quarterly 37: 443-55. [CrossRef]

Nichols, Curt. 2012. The Presidential Ranking Game: Critical Review and Some New Discoveries. Presidential Studies Quarterly 42: 275-99. [CrossRef]

Niemi, Richard G., and Jane Junn. 2005. Civic Education: What Makes Students Learn. New Haven: Yale University Press.

Page, Benjamin I., and Robert Y. Shapiro. 1992. The Rational Public: Fifty Years of Trends in Americans' Policy Preferences. Chicago: University of Chicago Press. 
Panagopoulos, Costas. 2012. Ex-Presidential Approval: Retrospective Evaluations of Presidential Performance. Presidential Studies Quarterly 42: 719-29. [CrossRef]

Prior, Markus. 2005. News vs. Entertainment: How Increasing Media Choice Widens Gaps in Political Knowledge and Turnout. American Journal of Political Science 49: 577-92. [CrossRef]

Ridings, William J., Jr., and Stuart B. McIver. 1997. Rating the Presidents: A Ranking of U.S. Leaders, from the Great and Honorable to the Dishonest and Incompetent. Secaucus: Citadel Press.

Roberts, Scott L., and Brandon M. Butler. 2012. Idealizing and Localizing the Presidency: The President's Place in State History Textbooks. In The New Politics of the Textbook. Edited by Hickman, Heather and Brad J. Porfilio. Boston: Sense Publishers, pp. 287-303.

Rottinghaus, Brandon, and Justin Vaughn. 2015. Measuring Obama against the Great Presidents. In The Brookings Institution; February 13. Available online: https:/ /www.brookings.edu/blog/fixgov/2015/02/13/ measuring-obama-against-the-great-presidents / (accessed on 9 February 2017).

Sanchez, J. M. 1996a. Old Habits Die Hard: The Textbook Presidency Is Alive and Well. P.S.: Political Science and Politics 29: 63-66.

Sanchez, J. M. 1996b. Mediocrity at the Helm: Evaluations of the President in Political Science Textbooks. The Social Science Journal 33: 97-111. [CrossRef]

Schlesinger, Arthur M., Sr. 1948. Historians Rate the U.S. Presidents. Life 25: 65-66, 68, 73-74.

Schlesinger, Arthur M. 1962. Our Presidents: A Rating by 75 Historians. New York Times Magazine, July 28, 12-43.

Schlesinger, Arthur M., Jr. 1997. Rating the Presidents: Washington to Clinton. Political Science Quarterly 112: 179-90. [CrossRef]

Sienna College Research Institute. 2010. U. S. President's Study. Available online: https:/ /www.siena.edu/centersinstitutes/siena-research-institute/social-cultural-polls/us-presidents-study/ (accessed on 9 February 2017).

Simon, Dennis M. 2009. Public Expectations of the President. In The Oxford Handbook of the American Presidency. Edited by Edwards, George C., III and William G. Howell. New York: Oxford University Press, pp. 135-59.

Simon, Arthur M., and Joseph E. Uscinski. 2012. Prior Experience Predicts Presidential Performance. Presidential Studies Quarterly 42: 514-48. [CrossRef]

Simonton, Dean Keith. 1987. Why Presidents Succeed: A Political Psychology of Leadership. New Haven: Yale University Press.

Simonton, Dean Keith. 1991. Predicting Presidential Greatness: An Alternative to the Kenney and Rice Contextual Index. Presidential Studies Quarterly 21: 301-5.

Simonton, Dean Keith. 1992. Presidential Greatness and Personality: A Response to McCann (1992). Journal of Personality and Social Psychology 63: 676-79. [CrossRef]

Simonton, Dean Keith. 1993. Putting the Best Leaders in the White House: Personality, Policy, and Performance. Political Psychology 14: 537-48. [CrossRef]

Simonton, Dean Keith. 2001. Predicting Presidential Performance in the United States: Equation Replication on Recent Survey Results. Journal of Social Psychology 141: 293-307. [CrossRef] [PubMed]

Simonton, Dean Keith. 2002. Intelligence and Presidential Greatness: Equation Replication Using Updated IQ Estimates. Advances in Psychology Research 13: 143-53.

Simonton, Dean Keith. 2006. Presidential IQ, Openness, Intellectual Brilliance, and Leadership: Estimates and Correlations for 42 US Chief Executives. Political Psychology 27: 511-26. [CrossRef]

Simonton, Dean Keith. 2008. Presidential Greatness and Its Socio-Psychological Significance: Individual or Situation? Performance or Attribution? In Leadership at the Crossroads. Edited by Ciulla, Joanne B., Crystal L. Hoyt, Donelson R. Forsyth, George R. Goethals, Lori Cox Han and Michael A. Genovese. New York: Praeger, pp. 132-48.

Simonton, Dean Keith. 2013. Presidential Leadership: Performance Criteria and Their Predictors. In The Oxford Handbook of Leadership. Edited by Rumsey, Michael G. New York: Oxford University Press, pp. 327-43.

Thies, Clifford F. 2014. Ranking the Presidents: Scholars versus the People. Academic Questions 27: 79-93. [CrossRef]

Uscinski, Joseph E., and Arthur Simon. 2011. Partisanship as a Source of Presidential Rankings. White House Studies 11: 1-14. 
Waterman, Richard, Carol L. Silva, and Hank Jenkins-Smith. 2014. The Presidential Expectations Gap. Ann Arbor: University of Michigan Press.

Zernicke, Paul Haskell. 1993. Presidents on the Textbook Presidency. The Social Science Journal 30: 401-17. [CrossRef]

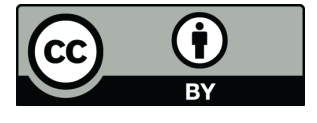

(c) 2018 by the author. Licensee MDPI, Basel, Switzerland. This article is an open access article distributed under the terms and conditions of the Creative Commons Attribution (CC BY) license (http:/ / creativecommons.org/licenses/by/4.0/). 